\title{
Antiviral efficacy of entecavir for hepatitis $B$ virus rtA181V/T mutants
}

\author{
Ping $\mathrm{Li}^{1}$, Jiabao Geng ${ }^{1}$, Wei $\mathrm{Li}^{2}$, Xiaobing Xư ${ }^{3}$, Xin Zhang ${ }^{1}$, Wenkai Zheng ${ }^{1}$, Yuecheng Yu', Zhiguo Yang ${ }^{1}$ \\ and Maorong Wang ${ }^{1 *}$
}

\begin{abstract}
Background: The amino acid substitution at position 181 of the Hepatitis B virus (HBV) polymerase is a multi-drug resistance affecting both the L-nucleoside and acyclic phosphonate nucleotide groups. Data is limited on the efficacy of entecavir (ETV) rescuing chronic hepatitis B (CHB) patients with rtA181T/N mutation.

Methods: Thirty-one patients with rtA181TN mutation and 25 patients with rtA181T/N and rtN236T mutation were enrolled. Virological, serological and biochemical outcomes of ETV rescue therapy over 12 months in CHB patients with rtA181T/N mutation strains were investigated. All patients were treated with ETV $0.5 \mathrm{mg} /$ day for 12 months and scheduled follow-up every 3 months. Patients' characteristics, laboratory tests results and clinical outcomes were collected and compared.
\end{abstract}

Results: After emergence of rtA181TN mutant, serum HBV DNA levels increased over $4 \log 10 \mathrm{IU} / \mathrm{mL}$, but the total bilirubin, alanine aminotransferase (ALT) levels raised moderately. No significant difference in baseline characteristics was observed between the rtA181TN group and rtA181TN + rtN236T group. After 12 months rescue therapy, total 85.7\% (48/56) patients achieved HBV DNA undetectable. No significant difference in the mean reduction of serum HBV DNA and biochemical response was observed between both groups ( $3.59 \pm 1.85 \mathrm{vs} .3 .76 \pm 2.15 \mathrm{log} 10 \mathrm{IU} / \mathrm{ml}$; $P=0.756$ and 90.3 vs. $80.0 \% ; P=0.272$, respectively). The mean HBV DNA reduction, HBsAg and ALT levels were also similar between different rtA181T/sW172 mutations $(P>0.05)$. HBV DNA level is the only predictor of 12 months antiviral outcomes (odds ratio 6.723, $P=0.022$ ).

Conclusions: The results of the present study suggested that ETV is efficient in rescuing rtA181TN mutation CHB patients. HBV DNA level could predict viral clearance at the $12^{\text {th }}$ month.

Keywords: Chronic hepatitis B, Nucleoside and nucleotide analogs (NAs), Entecavir, Mutation

\section{Background}

Hepatitis B virus (HBV) infection is a major health problem that caused over 350 million people suffering chronic infection worldwide $[1,2]$. Nucleos(t)ide analogs (NAs) including lamivudine (LAM), adefovir dipivoxil (ADV), entecavir (ETV), telbivudine (LDT) and tenofovir(TDF) are currently approved to suppress HBV replication so as to prevent the progression of liver diseases. However, NAs need sustained treatment because it can not remove covalently closed circular DNA in the nucleus. During the long-term antiviral treatment, drug resistance begins with

\footnotetext{
* Correspondence: maorongwang@yeah.net

${ }^{1}$ Department of Liver Disease Center, Bayi Hospital Affiliated Nanjing

University of Chinese Medicine, Nanjing, Jiangsu Province, China

Full list of author information is available at the end of the article
}

mutations in the polymerase gene, leading to an increase in viral load and serum alanine aminotransferase (ALT) levels, progression of liver disease, even causing liver cirrhosis or failure. Drug resistance has become a major problem during antiviral treatment.

According to resistance patterns, NAs drugs can be structurally grouped as L-nucleoside (LAM, LDT), acyclic nucleotide phosphonate (ADV, TDF), and D-cyclopentanes (ETV). The amino acid substitution at position 181 of the HBV polymerase is a multi-drug resistance which could affect both the L-nucleoside and acyclic phosphonate nucleotide groups [3]. Additionally, in vitro studies have found the rtA181T/V mutation could affect virus replication [4], protein secretion [5] and tumorigenesis [6, 7]. Switching to ETV for rtA181T/V mutation patients was recommended 
by the Asian Pacific Association for the Study of the Liver (APASL) [8]. But few studies reported the effect of ETV in rescuing rtA181T/V mutation patients.

In general, the majority of $\mathrm{HBV}$ rtA181V/T mutants are known to be induced after ADV therapy, along with the rtN236T mutant. Therefore, we aimed to evaluate the antiviral efficacy of 12 months ETV rescue therapy in $\mathrm{rtA181T/V}$ single mutation or with rtN236T mutant.

\section{Methods \\ Patients}

A total number of $56 \mathrm{CHB}$ patients, who visited our hospital during January 2010 to May 2014, were enrolled in this study. They developed rtA181T/V mutation strains during ADV treatment. Among them, 31 patients developed rtA181T/V mutation strains (rtA181 group), and the other 25 patients developed rtA181T/V and rtN236T mutation strains (rtA181 + rtN236 group). No other HBV RT mutants were detected except rtA181 and rtN236. These patients were treated with $0.5 \mathrm{mg} /$ day ETV for at least 12 months and scheduled follow-up every 3 months. Patients who received IFN- $\alpha$ treatment or co-infected with hepatitis $\mathrm{C}$, hepatitis $\mathrm{D}$, or human immunodeficiency virus were excluded from this study. The diagnostic criteria were based on the Management Scheme of Diagnostic and Therapy Criteria of Viral Hepatitis issued by the Chinese Society of Infectious Diseases. This study was approved by the institutional review board of China Nanjing bayi hospital and all aspects of the study comply with the Declaration of Helsinki. The Ethics Committee specifically approved that no informed consent was required because this was a retrospective study and the data were analyzed anonymously.

\section{Serum assay}

ALT, aspartate aminotransferase (AST), and total bilirubin in serum were measured by the Olympus AU5400 Chemistry System (Beckman Coulter, Switzerland). Viral markers, including hepatitis B surface antigen, hepatitis B e antigen ( $\mathrm{HBeAg})$, and anti-HBe, were tested by Chemiluminescent Assay (Architect i2000SR; Abbott Diagnostics, Abbott Park, IL, USA). HBV DNA was quantified by real-time PCR using a commercial detection kit (Kehua Bio-Engineering) with the aid of Light Cycler Detection System (ABI 7300 Realtime PCR system, USA). The lower limit of detection for this assay is $50 \mathrm{IU} / \mathrm{mL}$.

HBV resistance mutations were identified by DNA sequencing. The fragments (nt130-nt1129), encompassing the reverse transcriptase (RT) domain, were amplified by nested PCR. The first pair of primers for the PCR were $5^{\prime}-$ AAGCTCTGCTAGATCCCAGAGT-3' (sense: nt18-nt40) and 5' '-TTTCGCTCCAGACCGGCTGC-3' (antisense: nt1 $320-n t 1301)$. The second pair of primers for the PCR included 5'-GCGGGGTTTTTCTTGTTGAC-3' (sense: nt5 6-nt75) and 5'-AGTATGGATCGGCAGAGGAG-3' (anti sense: nt1272-nt1253). PCR products were directly sequenced on an automated DNA sequencer (ABI 3730XL, USA) using the second sense primer. Substitutions at positions rt80, rt173, rt180, rt181, rt184, rt202, rt204, rt236, and rt250 were taken as resistance mutations for analysis [9].

\section{Statistical analysis}

Serum HBV DNA levels and HBsAg titers were expressed on a logarithmic scale. Quantitative data were expressed as means \pm standard deviations and analyzed by independent samples $t$ test or the Mann-Whitney $U$ test. Count data constitution were analyzed by chisquared test. Multivariate analysis was performed by a logistic regression model. Statistical analysis was carried out with the aid of SPSS 13.0 software. The significance was set at $P<0.05$.

\section{Results \\ Study population}

In $56 \mathrm{CHB}$ patients appeared rtA181T/V mutation, 51 (91.1\%) were male and 5 (8.9\%) were female, and the mean age was $42.1 \pm 8.6$ years. After emergence of $\mathrm{rtA} 181 \mathrm{~T} / \mathrm{V}$ mutant, mean serum HBV DNA increased over $4 \log _{10} \mathrm{IU} / \mathrm{mL}$. There were no statistically significant differences between these two groups regarding mean age, sex ratio, liver functions, HBV DNA level, HBsAg titer and $\mathrm{HBeAg}$ positive rate. The baseline characteristics of the two study groups were presented in Table 1.

\section{Virological responses}

The mean changes in serum HBV DNA at 6th month and 12th month were shown in Table 2. According to baseline, the mean serum HBV DNA at $6^{\text {th }}$ month and $12^{\text {th }}$ month were significantly reduced not only in rtA181 group but also in rtA181 $+\mathrm{rtN2} 26$ group $(P<0.001)$. However, the mean reduction of serum HBV DNA at $6^{\text {th }}$ month did not differ significantly between the rtA181T/V group $(3.18 \pm$ $1.92 \log 10 \mathrm{IU} / \mathrm{ml})$ and the rtA181 $+\mathrm{rtN} 236$ group $(3.52 \pm$ $2.04 \log 10 \mathrm{IU} / \mathrm{ml})(P=0.520)$. In addition, no statistical difference in the mean decline of serum HBV DNA at $12^{\text {th }}$ month was observed between the two groups $(3.59 \pm 1.85$ vs. $3.76 \pm 2.15 \log 10 \mathrm{IU} / \mathrm{ml} ; P=0.756)$.

After $12^{\text {th }}$ month treatment, the mean serum HBV DNA of the 7 patients who did not achieve undetectable HBV DNA was $4.16 \pm 1.16 \log 10 \mathrm{IU} / \mathrm{ml}$ (range 2.77 to $5.71 \log 10 \mathrm{IU} / \mathrm{ml})$.

\section{Serologic responses}

HBeAg status during treatment was shown in Table 2. The rates of HBeAg loss were similar between the rtA181 group and the rtA181 $+\mathrm{rtN} 236$ group (1.3 vs. $5.6 \%, P=0.448$ at the $6^{\text {th }}$ month; 20.8 vs. $11.1 \% ; P=0.403$ at the 12 th month). 
Table 1 Characteristics of HBV rtA181TN mutant patients

\begin{tabular}{|c|c|c|c|}
\hline Characteristics & $\begin{array}{l}\text { rtA181 group } \\
(n=31)\end{array}$ & $\begin{array}{l}\text { rtA181 + rtN236 } \\
\text { group }(n=25)\end{array}$ & $P$ value \\
\hline \multicolumn{4}{|l|}{ Age (years) } \\
\hline Mean \pm SD & $42.4 \pm 9.5$ & $41.7 \pm 7.6$ & 0.763 \\
\hline \multicolumn{4}{|l|}{ Sex (No.) } \\
\hline Male/Female & $27 / 4$ & $24 / 1$ & 0.245 \\
\hline \multicolumn{4}{|c|}{ Total bilirubin level ( $\mu \mathrm{mol} / \mathrm{L})$} \\
\hline Mean \pm SD & $17.2 \pm 8.0$ & $16.2 \pm 8.2$ & 0.671 \\
\hline \multicolumn{4}{|l|}{$\mathrm{ALT}(\mathrm{U} / \mathrm{L})$} \\
\hline Mean \pm SD & $81.4 \pm 88.4$ & $162.2 \pm 316.4$ & 0.226 \\
\hline \multicolumn{4}{|l|}{ AST (U/L) } \\
\hline Mean \pm SD & $47.0 \pm 31.4$ & $79.8 \pm 124.7$ & 0.210 \\
\hline \multicolumn{4}{|c|}{ HBV DNA $\left(\log _{10} I U / m L\right)$} \\
\hline Mean \pm SD & $4.15 \pm 1.87$ & $4.35 \pm 1.71$ & 0.678 \\
\hline \multicolumn{4}{|l|}{$\mathrm{HBsAg}\left(\log _{10} \mathrm{IU} / \mathrm{ml}\right)$} \\
\hline Mean \pm SD & $3.57 \pm 0.37$ & $3.63 \pm 0.39$ & 0.561 \\
\hline \multicolumn{4}{|l|}{ HBeAg (No.) } \\
\hline Positive/Negative & $24 / 7$ & $18 / 7$ & 0.642 \\
\hline
\end{tabular}

Table 2 Virological and Biochemical Responses During ETV Rescue Therapy

\begin{tabular}{|c|c|c|c|}
\hline Response & $\begin{array}{l}\text { rtA181 group } \\
(n=31)\end{array}$ & $\begin{array}{l}\text { rtA181 }+ \text { rtN236 } \\
\text { group }(n=25)\end{array}$ & $P$ value \\
\hline \multicolumn{4}{|l|}{ Virological } \\
\hline \multicolumn{4}{|c|}{ HBV DNA Reduction $\left(\log _{10} \mathrm{IU} / \mathrm{mL}\right)$} \\
\hline $6^{\text {th }}$ Month $($ Mean $\pm S D)$ & $3.18 \pm 1.92$ & $3.52 \pm 2.04$ & 0.520 \\
\hline $12^{\text {th }}$ Month (Mean \pm SD) & $3.59 \pm 1.85$ & $3.76 \pm 2.15$ & 0.756 \\
\hline \multicolumn{4}{|l|}{ undectectable } \\
\hline $6^{\text {th }}$ Month (No. \%) & $24 / 31(77.4 \%)$ & 19/25 (76.0\%) & 0.900 \\
\hline $12^{\text {th }}$ Month (No. \%) & $27 / 31(87.1 \%)$ & $22 / 25(88.0 \%)$ & 0.919 \\
\hline \multicolumn{4}{|l|}{ HBeAg loss } \\
\hline $6^{\text {th }}$ Month (No. \%) & $3 / 24(1.3 \%)$ & $1 / 18(5.6 \%)$ & 0.448 \\
\hline $12^{\text {th }}$ Month (No. \%) & $5 / 24(20.8 \%)$ & $2 / 18(11.1 \%)$ & 0.403 \\
\hline \multicolumn{4}{|l|}{ Biochemical } \\
\hline \multicolumn{4}{|l|}{ Total bilirubin level $(\mu \mathrm{mol} / \mathrm{L})$} \\
\hline $6^{\text {th }}$ Month $($ Mean $\pm S D)$ & $16.0 \pm 10.0$ & $14.3 \pm 4.7$ & 0.440 \\
\hline $12^{\text {th }}$ Month (Mean \pm SD) & $16.3 \pm 8.9$ & $14.4 \pm 3.7$ & 0.329 \\
\hline \multicolumn{4}{|l|}{ Normalization of serum Tbil } \\
\hline $6^{\text {th }}$ Month (No. \%) & $26 / 31(\%)$ & $22 / 25(72.0 \%)$ & 0.661 \\
\hline $12^{\text {th }}$ Month (No. \%) & $24 / 31(89.6 \%)$ & $22 / 25(88.0 \%)$ & 0.304 \\
\hline \multicolumn{4}{|l|}{$\mathrm{ALT}(\mathrm{U} / \mathrm{L})$} \\
\hline $6^{\text {th }}$ Month $($ Mean $\pm S D)$ & $38.3 \pm 20.6$ & $37.7 \pm 15.0$ & 0.903 \\
\hline $12^{\text {th }}$ Month (Mean \pm SD) & $37.2 \pm 18.4$ & $34.3 \pm 12.2$ & 0.500 \\
\hline \multicolumn{4}{|l|}{ Normalization of serum ALT } \\
\hline $6^{\text {th }}$ Month (No. \%) & $23 / 31(74.2 \%)$ & $21 / 25$ (84.0\%) & 0.374 \\
\hline $12^{\text {th }}$ Month (No. \%) & $28 / 31(90.3 \%)$ & $20 / 25$ (80.0\%) & 0.272 \\
\hline
\end{tabular}

\section{Biochemical responses}

The serum total bilirubin and ALT levels decreased after 6 months ETV rescue therapy in both groups (Table 2). The liver functions and normalization between the two groups did not differ significantly not only at the 6th month but also at the 12 th month $(P>0.05)$.

\section{Responses between different rtA181T/sW172 mutations}

The rtA181T substitution was mainly associated with an sW172* substitution, only $15.4 \%(4 / 26)$ had other missense mutations (three with sW172L, one with sW172S).

After emergence of mutant, the serum HBV DNA, HBsAg and ALT levels did not differ significantly between the rtA181T/sW172* mutation group and other missense mutations group (4.16 versus $3.61 \log 10 \mathrm{IU} / \mathrm{mL} ; P=0.298,3.52$ versus $3.46 \log 10 \mathrm{IU} / \mathrm{mL} ; P=0.795,142.5$ versus $59.0 \mathrm{U} / \mathrm{L} ; P$ $=0.524$, respectively). Throughout the treatment period, serum HBV DNA decreased progressively in the two groups. However, the mean HBV DNA reduction, HBsAg and ALT levels were also similar between the two groups at the 6th month and the 12th month $(\mathrm{P}>0.05)$, as shown in Table 3.

Baseline predictive factors for serum HBV DNA negativity After multivariate analysis with adjustment for baseline variables (groups, sex, age, HBsAg level, HBeAg status; serum HBV DNA level, total bilirubin level, ALT and AST level) for all 56 patients, HBV DNA level was the independent covariate to be inversely associated with serum HBV DNA negativity at the 12 th month $(P=0.022)$, as shown in Table 4 .

Table 3 Responses between different rtA181T/sW172 mutations

\begin{tabular}{|c|c|c|c|}
\hline Characteristics & $\begin{array}{l}\text { rtA181T/sW172* } \\
\text { mutation } \\
\text { group }(n=22)\end{array}$ & $\begin{array}{l}\text { other missense } \\
\text { mutations } \\
\text { group }(n=4)\end{array}$ & $P$ value \\
\hline \multicolumn{4}{|l|}{ Before Rescue } \\
\hline \multicolumn{4}{|l|}{ HBV DNA $\left(\log _{10} \mathrm{IU} / \mathrm{mL}\right)$} \\
\hline Mean \pm SD & $4.16 \pm 2.35$ & $3.61 \pm 0.21$ & 0.298 \\
\hline \multicolumn{4}{|l|}{ HBsAg (lg IU/ml) } \\
\hline Mean \pm SD & $3.52 \pm 0.48$ & $3.46 \pm 0.40$ & 0.795 \\
\hline \multicolumn{4}{|l|}{$\operatorname{ALT}(\mathrm{U} / \mathrm{L})$} \\
\hline Mean \pm SD & $142.5 \pm 253.8$ & $59.0 \pm 40.9$ & 0.524 \\
\hline \multicolumn{4}{|l|}{ After Rescue } \\
\hline \multicolumn{4}{|c|}{ HBV DNA Reduction $\left(\log _{10} \mathrm{IU} / \mathrm{mL}\right)$} \\
\hline 6th Month (Mean $\pm S D$ ) & $3.31 \pm 2.25$ & $3.61 \pm 0.21$ & 0.797 \\
\hline 12th Month (Mean \pm SD) & $3.66 \pm 2.18$ & $3.61 \pm 0.21$ & 0.918 \\
\hline \multicolumn{4}{|l|}{$\mathrm{HBsAg}\left(\log _{10} \mathrm{IU} / \mathrm{ml}\right)$} \\
\hline 6th Month (Mean \pm SD) & $3.50 \pm 0.45$ & $3.47 \pm 0.42$ & 0.908 \\
\hline 12th Month (Mean \pm SD) & $3.31 \pm 0.50$ & $3.14 \pm 0.50$ & 0.529 \\
\hline \multicolumn{4}{|l|}{$\mathrm{ALT}(\mathrm{U} / \mathrm{L})$} \\
\hline 6th Month (Mean $\pm S D)$ & $39.6 \pm 19.3$ & $20.5 \pm 11.7$ & 0.069 \\
\hline 12th Month (Mean \pm SD) & $39.0 \pm 20.0$ & $23.5 \pm 3.1$ & 0.142 \\
\hline
\end{tabular}




\section{Discussion}

In this study, we evaluated the virological, serological, and biochemical outcomes of ETV rescue therapy in patients who developed HBV rtA181T/V mutation strains and compared the ETV rescue therapy efficacy between rtA181T/V mutation and rtA181T/V + rtN236T mutation patients. Serum HBV DNA levels declined to undetectable levels $(<50 \mathrm{IU} / \mathrm{mL})$ in 43 of 56 patients (76.8\%) after 6 months rescue therapy, and the overall HBV DNA undetectable at the 12th month reached 87.5\% (49/56). All therapeutic responses of ETV rescue, including decline of serum HBV DNA, virological, biochemical, and serological responses did not differ significantly between the rtA181T/V group and rtA181T $/ \mathrm{V}+\mathrm{rtN236T}$ group $(P>0.05)$. In addition, HBV DNA level was the predictor of 12 months antiviral outcomes.

The rtA $181 \mathrm{~T} / \mathrm{V}$ is a cross-resistance mutation. in vitro studies found the mutant strain induces a decreased susceptibility to LAM (<10-fold), ADV (2- to 8-fold) and TDF (2- to 3-fold), but it is still susceptible to ETV [10]. We evaluated the efficacy of ETV in rescuing patients with rtA181T/V mutation strain and rtA181T/V + rtN236T mutation strain. In the present study, mean HBV DNA level increased over $4 \log _{10} \mathrm{IU} / \mathrm{mL}$ after rtA181T/V mutant emergence,but the total bilirubin, ALT and AST level raised moderately, which suggested that the antiviral drug still showed partial effect to rtA181T/V mutant strain, or the mutant virus defective. These explained that many patients who continued previously treatment could partly improve biochemical and virological results after occurring $\mathrm{rtA} 181 \mathrm{~T} / \mathrm{V}$ mutant. This finding was similar to the study in LAM resistance [11].

After ETV rescue therapy, post-treatment HBV DNA level declined significantly. About $87.5 \%$ patients achieved

Table 4 Multivariate Analysis of Baseline Factors Predictive of Serum HBV DNA Negativity After 12 months of ETV Rescue Therapy

\begin{tabular}{lcccl}
\hline Varibles & $\begin{array}{l}\text { Regression } \\
\text { Coefficient }\end{array}$ & $\begin{array}{l}\text { Standard } \\
\text { Error }\end{array}$ & $P$ Value & OR $(95 \% \mathrm{Cl})$ \\
\hline $\begin{array}{l}\text { Mutation } \\
\text { group }\end{array}$ & 0.487 & 1.515 & 0.748 & $1.627(0.084-31.666)$ \\
$\begin{array}{l}\text { HBV DNA } \\
\text { level }\end{array}$ & 1.906 & 0.832 & 0.022 & $6.723(1.315-24.371)$ \\
$\begin{array}{l}\text { HBsAg } \\
\text { level }\end{array}$ & 4.749 & 3.319 & 0.152 & $115.522(0.173-77176.906)$ \\
eAg & -1.696 & 1.542 & 0.271 & $0.183(0.009-3.765)$ \\
Sex & 2.256 & 1.733 & 0.193 & $9.545(0.320-285.099)$ \\
Age. & 0.064 & 0.095 & 0.501 & $1.066(0.885-1.284)$ \\
Tbil & -0.294 & 0.183 & 0.108 & $0.745(0.520-1.067)$ \\
ALT & 0.001 & 0.016 & 0.927 & $1.001(0.971-1.033)$ \\
AST & 0.002 & 0.038 & 0.951 & $1.002(0.931-1.080)$ \\
\hline
\end{tabular}

undetectable HBV DNA $(<50 \mathrm{IU} / \mathrm{mL})$ at the 12 th month, which was equivalent to the results of treatment-naïve patients $(67 \%$ and $90 \%)[12,13]$. The ALT normalization rate $(82.1 \%)$ at the 12 th month in our analysis was higher than these studies (67 and 78\%) [12, 13]. This perhaps resulted from the difference of pre-treatment ALT levels (117U/L vs. $141 \mathrm{U} / \mathrm{L})$. In $42 \mathrm{HBeAg}$ positive patients, $\mathrm{HBeAg}$ loss after 12 months treatment was $12.5 \%$, approaching to treatment-naïve patients [13]. Buti et al. reported that high pre-treatment baseline HBV DNA levels were risk factor for increased antiviral drug resistance and attenuation of virological response in ADV treatment patients [14]. Our study indicated the similar result that ETV was effective in $\mathrm{rtA} 181 \mathrm{~T} / \mathrm{V}$ mutation patients. HBV DNA level was the only factor that predicted viral clearance.

A recent study has shown that rtA181T mutants with or without $\mathrm{S}$ truncation had different virological characteristics. They found the serum levels of HBV DNA and HBsAg in pHBV-rtA181T/sW172* injected mice were significantly lower than that of pHBV-rtA181T/sW172L injected mice [15]. Unfortunately, we could not demonstrate any difference between the two rtA181T mutants. The possible reason was that hepatitis $\mathrm{B}$ virus mutant coexisting with wild type virus, which rescues the replication defective in patients [16].

TDF, which is known to be a high barrier HBV inhibitor, has already been used in China. However, Villet has reported rtA181V/T mutants had a slight decrease in susceptibility to TDF [10]. Antiviral efficacy of TDF for $\mathrm{HBV}$ rtA181V/T mutants is still unclear in practice [17]. Further investigation of rescue therapy, including TDF, for $\mathrm{HBV}$ rtA181V/T mutants alone will be necessary.

In summary, this is the first study to investigate the efficacy of ETV in rescuing CHB patients in rtA181T/V mutation and rtA181T/V + rtN236T mutation patients. The results of the present study indicate that ETV is efficient in rescuing $\mathrm{rtA} 181 \mathrm{~T} / \mathrm{V}$ mutation patients and the HBV DNA level is the only predictor of 12 months antiviral outcomes. There were still some limitations in this study. This research was conducted retrospectively, with an insufficient number of subjects. Thus, there might be a limitation of selection bias. In addition, the follow-up period of our study was relatively short, long-term studies were warranted to evaluate the long-time efficacy of ETV rescue therapy in patients with $\mathrm{rtA} 181 \mathrm{~T} / \mathrm{V}$ mutation.

\section{Conclusions}

Our results indicated that ETV is efficient in rescuing rtA181T/V mutation CHB patients and HBV DNA level could predict viral clearance at the 12th month. That provides clinical evidence for achievement of further antiviral efficacy in NA-related HBV mutants. 


\section{Abbreviations}

ADV: Adefovir dipivoxil; ALT: Alanine aminotransferase; AST: Aspartate aminotransferase; CHB: Chronic hepatitis B; ETV: Entecavir; HBeAg: Hepatitis B e antigen; HBsAg: Hepatitis B surface antigen; HBV: Hepatitis B virus; LAM: Lamivudine; LDT: Telbivudine; NAs: Nucleos(t)ide analogs; TDF: Tenofovir

\section{Acknowledgements}

We thank the anonymous referees and the editor for their comments and suggestions that helped improve the manuscript.

\section{Funding}

This study was supported by Chinese mega-project of science research (2008ZX10002004-001-024)

\section{Availability of data and materials}

The datasets during and/or analyzed during the current study available from the corresponding author on reasonable request.

\section{Authors' contributions}

Study's conception: LP,YZG, WMR; Study's design: LP, WMR; Study's performance: $L P, G J B, L W$; Writing and revision: $L P, X X B, Z X, Z W K, Y Y C$. All authors read and approved the final manuscript.

\section{Competing interests}

The authors declare that they have no competing interests.

\section{Consent for publication}

Not applicable. No personal data were collected in the context of this study.

\section{Ethics approval and consent to participate}

This study was performed with the approval of the institutional review board of China Nanjing bayi hospital and all aspects of the study comply with the Declaration of Helsinki. The Ethics Committee specifically approved that no informed consent was required because this was a retrospective study and the data were analyzed anonymously.

\section{Publisher's Note}

Springer Nature remains neutral with regard to jurisdictional claims in published maps and institutional affiliations.

\section{Author details}

${ }^{1}$ Department of Liver Disease Center, Bayi Hospital Affiliated Nanjing University of Chinese Medicine, Nanjing, Jiangsu Province, China. ${ }^{2}$ Department of Infection Disease Center, Henan Province People's Hospital, Zhengzhou, Henan Province, China. ${ }^{3}$ Department of Gastroenterology and Hepatology, Nanjing General Hospital of Nanjing Military Command, Nanjing, Jiangsu Province, China.

Received: 23 January 2017 Accepted: 28 March 2017

Published online: 04 April 2017

\section{References}

1. Dienstag JL. Hepatitis B virus infection. N Engl J Med. 2008:359:1486-500

2. Lozano R, Naghavi M, Foreman K, Lim S, Shibuya K, Aboyans V, Abraham J, Adair T, Aggarwal R, Ahn SY, Alvarado M, Anderson HR, Anderson LM, Andrews KG, Atkinson C, Baddour LM, Barker-Collo S, Bartels DH, Bell ML, Benjamin EJ, Bennett D, Bhalla K, Bikbov B, Bin AA, Birbeck G, Blyth F, Bolliger I, Boufous S, Bucello C, Burch M, Burney P, Carapetis J, Chen H, Chou D, Chugh SS, Coffeng LE, Colan SD, Colquhoun S, Colson KE, Condon J, Connor MD, Cooper LT, Corriere M, Cortinovis M, de Vaccaro KC, Couser W, Cowie BC, Criqui MH, Cross M, Dabhadkar KC, Dahodwala N, De Leo D, Degenhardt L, Delossantos A, Denenberg J, Des Jarlais DC, Dharmaratne SD, Dorsey ER, Driscoll T, Duber H, Ebel B, Erwin PJ, Espindola P, Ezzati M, Feigin $V$, Flaxman AD, Forouzanfar MH, Fowkes FG, Franklin R, Fransen M, Freeman MK, Gabriel SE, Gakidou E, Gaspari F, Gillum RF, Gonzalez-Medina D, Halasa YA, Haring D, Harrison JE, Havmoeller R, Hay RJ, Hoen B, Hotez PJ, Hoy D, Jacobsen KH, James SL, Jasrasaria R, Jayaraman S, Johns N, Karthikeyan G, Kassebaum N, Keren A, Khoo JP, Knowlton LM, Kobusingye O, Koranteng A, Krishnamurthi R, Lipnick M, Lipshultz SE, Ohno SL, Mabweijano J, Maclntyre MF, Mallinger L, March L, Marks GB, Marks R, Matsumori A, Matzopoulos R, Mayosi BM, McAnulty JH, McDermott MM, McGrath J, Mensah GA, Merriman
TR, Michaud C, Miller M, Miller TR, Mock C, Mocumbi AO, Mokdad AA, Moran A, Mulholland K, Nair MN, Naldi L, Narayan KM, Nasseri K, Norman P, O'Donnell M, Omer SB, Ortblad K, Osborne R, Ozgediz D, Pahari B, Pandian JD, Rivero AP, Padilla RP, Perez-Ruiz F, Perico N, Phillips D, Pierce K, Pope CR, Porrini E, Pourmalek F, Raju M, Ranganathan D, Rehm JT, Rein DB, Remuzzi G, Rivara FP, Roberts T, De Leon FR, Rosenfeld LC, Rushton L, Sacco RL, Salomon JA, Sampson U, Sanman E, Schwebel DC, Segui-Gomez M, Shepard DS, Singh D, Singleton J, Sliwa K, Smith E, Steer A, Taylor JA, Thomas B, Tleyjeh IM, Towbin JA, Truelsen T, Undurraga EA, Venketasubramanian N, Vijayakumar L, Vos T, Wagner GR, Wang M, Wang W, Watt K, Weinstock MA, Weintraub R, Wilkinson JD, Woolf AD, Wulf S, Yeh PH, Yip P, Zabetian A, Zheng ZJ, Lopez AD, Murray CJ, AlMazroa MA, Memish ZA. Global and regional mortality from 235 causes of death for 20 age groups in 1990 and 2010: a systematic analysis for the Global Burden of Disease Study 2010. Lancet. 2012:380:2095-128.

3. Zoulim F, Locarnini S. Optimal management of chronic hepatitis B patients with treatment failure and antiviral drug resistance. Liver Int. 2013;33 Suppl 1:116-24.

4. Yeh CT, Chien RN, Chu CM, Liaw YF. Clearance of the original hepatitis B virus YMDD-motif mutants with emergence of distinct lamivudine-resistant mutants during prolonged lamivudine therapy. Hepatology. 2000;31:1318-26.

5. Warner N, Locarnini S. The antiviral drug selected hepatitis B virus rtA181T/ sW172* mutant has a dominant negative secretion defect and alters the typical profile of viral rebound. Hepatology. 2008;48:88-98.

6. Lai MW, Yeh CT. The oncogenic potential of hepatitis B virus rtA181T/ surface truncation mutant. Antivir Ther. 2008;13:875-9.

7. Lai MW, Huang SF, Hsu CW, Chang MH, Liaw YF, Yeh CT. Identification of nonsense mutations in hepatitis B virus $S$ gene in patients with hepatocellular carcinoma developed after lamivudine therapy. Antivir Ther. 2009;14:249-61.

8. Liaw YF, Kao JH, Piratvisuth T, Chan HL, Chien RN, Liu CJ, Gane E, Locarnini S, Lim SG, Han KH, Amarapurkar D, Cooksley G, Jafri W, Mohamed R, Hou JL, Chuang WL, Lesmana LA, Sollano JD, Suh DJ, Omata M. Asian-Pacific consensus statement on the management of chronic hepatitis B: a 2012 update. Hepatol Int. 2012;6:531-61.

9. Xu Z, Liu Y, Xu T, Chen L, Si L, Wang Y, Ren X, Zhong Y, Zhao J, Xu D. Acute hepatitis $B$ infection associated with drug-resistant hepatitis B virus. J Clin Virol. 2010;48:270-4.

10. Villet S, Pichoud C, Billioud G, Barraud L, Durantel S, Trepo C, Zoulim F. Impact of hepatitis B virus rtA181V/T mutants on hepatitis B treatment failure. J Hepatol. 2008:48:747-55.

11. Sun J, Wang Z, Ma S, Zeng G, Zhou Z, Luo K, Hou J. Clinical and virological characteristics of lamivudine resistance in chronic hepatitis B patients: a single center experience. J Med Virol. 2005;75:391-8.

12. Chang TT, Gish RG, de Man R, Gadano A, Sollano J, Chao YC, Lok AS, Han KH, Goodman Z, Zhu J, Cross A, DeHertogh D, Wilber R, Colonno R, Apelian D. A comparison of entecavir and lamivudine for HBeAg-positive chronic hepatitis B. N Engl J Med. 2006;354:1001-10.

13. Lai CL, Shouval D, Lok AS, Chang TT, Cheinquer H, Goodman Z, DeHertogh D, Wilber R, Zink RC, Cross A, Colonno R, Fernandes L. Entecavir versus lamivudine for patients with $\mathrm{HBeAg}$-negative chronic hepatitis B. N Engl J Med. 2006;354:1011-20.

14. Buti M, Elefsiniotis I, Jardi R, Vargas V, Rodriguez-Frias F, Schapper M Bonovas S, Esteban R. Viral genotype and baseline load predict the response to adefovir treatment in lamivudine-resistant chronic hepatitis $B$ patients. J Hepatol. 2007;47:366-72.

15. Zhou LY, Chen EQ, Wang ML, Chen LL, Liu CP, Zeng F, Tang H. Biological characteristics comparison of HBV rtA181T mutants with truncated or substituted HBsAg expression in vitro and in vivo model systems. Sci Rep. 2016;6:39260.

16. Kim JH, Jung YK, Joo MK, Kin JH, Yim HJ, Park JJ, Kim JS, Bak YT, Yeon JE, Byun KS. Hepatitis B viral surface mutations in patients with adefovir resistant chronic hepatitis B with A181TN polymerase mutations. J Korean Med Sci. 2010;25:257-64.

17. Oh MJ, Lee HJ. Antiviral efficacy of entecavir versus entecavir plus adefovir for hepatitis B virus rtA181V/T mutants alone. Saudi J Gastroenterol. 2016;22:37-42. 